\title{
Editorial
}

\section{How to recover during and from a pandemic}

Over the past weeks, the world has changed. The COVID-19 pandemic has affected everyone, albeit in different ways and to a different degree. In the Netherlands, people could recently witness the pandemic taking its toll when the minister of medical care collapsed from exhaustion in the middle of a political debate. More mental breakdowns, particularly in health care workers, have surely happened outside the public eye and more will follow in the weeks to come. How can we prevent burnout rates from skyrocketing during these highly demanding times? One important ingredient for mental health, well-being and optimal functioning is sufficient and high-quality recovery outside working hours. However, this crisis also exemplifies the specific and divergent stressors and accompanying recovery needs of different groups of workers.

Health care workers are hardest hit by the corona crisis. Their work tasks and interactions with patients have changed completely. They face high workload in combination with high emotional and cognitive demands, often being forced to make important decisions with very limited time and support from co-workers. A second group of workers that keeps working through the crisis concerns workers with essential jobs that keep our societies going. Despite the importance of their jobs, the hard work and the long working hours they make, they are often marginalized, poorly paid and face high levels of job insecurity. Many of these workers even belong to the risk group but cannot afford to stay home and safe from contracting the virus. A third group of workers has (at least temporarily) lost their job in tourism, transportation or hospitality industry, or in small enterprises in retail or personal care industry. Only very few of these workers can work from home due to the nature of their work and many will suffer from economic hardship due to their lost income that may or may not be alleviated by government support.

For the most fortunate group of workers, the transition to work from home has been relatively easy. These workers are used to working from home occasionally and are equipped with the right tools and skills for remote work. Still, also for these workers, full-time telework is challenging. For instance, in our ongoing data collection in a large Dutch company, employees reported poor ergonomics and a lack of physical boundaries between their workspaces and the rest of their home. Moreover, juggling childcare, homeschooling and other domestic demands are major challenges for this group, particularly hitting single-parents or families with special needs (i.e., children or elderly who need special care). Boundaries between work and private life have vanished for these workers. Research on temporal and spatial flexibility of work has shown that people often work longer hours when working from home than at the office or extend their working days to make up for "lost time" during the day, spent on domestic chores or childcare, which is experienced as emotionally depleting ${ }^{1,2)}$. Even job control, which usually constitutes a job resource, may turn into a burden in teleworking when workers are forced to self-structure their entire working day and make sure to get their job tasks done ${ }^{3)}$. Participants of our study also perceive online meetings as more tiresome than face-toface meetings, due to absence of non-verbal cues, distorted speech or delayed body language.

What unifies all these workers is that most of them miss social interactions with their work community, worry about contracting the virus and have difficulties to deal with information overload on the horrendous consequences of the virus. Marital and family conflicts may be magnified. Existing mental problems such as depression and anxiety may worsen and many people suffer from feelings of loneliness, a risk factor that is as harmful to public health as well-established risk factors for mortality such as sedentary lifestyles, obesity or smoking ${ }^{4}$. Even if people cannot travel, regular days off help to balance these stressful work periods. According to my own research, geographical distance from work helps to increase mental distance. But leisure time spent at home also has beneficial effects, particularly if obligatory activities are avoided and time is spent on enjoyable, self-determined activities ${ }^{5)}$.

A model to help occupational psychologists guide initiatives on recovery is the DRAMMA model ${ }^{6}$, which combines insights from recovery research, leisure sciences and studies on self-determination theory ${ }^{7)}$. The model proposes that leisure time supports well-being through six mechanisms: Detachment, Relaxation, Autonomy, Mastery, Meaning and Affiliation. Detachment refers to 
mental disengagement from work-related tasks and can be achieved by creating mental and physical boundaries around one's work as well as engaging in physical activi$\operatorname{ties}^{8,9)}$. Relaxation refers to low levels of physical and mental activation combined with positive affect, experienced through activities such as massages, progressive muscle relaxation or a hot bath. Autonomy, i.e., a sense of having control over one's environment, can be achieved through purposely reserving certain periods of the day for enjoyable activities of one's own choice. Experiences of Mastery are sparked by leisure time spent on learning new skills (e.g., handicrafts, sports), hobby engagement or education (e.g., learning a language or about other topics of interest). Meaning is a hitherto under-researched mechanism in relation to recovery from job stress. But leisure research suggests that leisure activities that instigate a feeling of making a positive difference in the world such as volunteer work, creative activities which foster selfexpression, or leisure activities which empower oneself or others, help satisfying people's need for meaning ${ }^{10)}$. In a qualitative study in which researchers asked participants to imagine living their life as their "best possible self", they found that each DRAMMA mechanism was present in people's vision of living a good life ${ }^{11)}$.

Aligning with the idea that leisure time can be shaped according to people's needs, in our recently published Integrative Needs Model of Crafting ${ }^{12)}$, we describe how people can indeed proactively fulfill their psychological needs by crafting their various work- and non-work roles. This model is grounded in the idea that workers modify their thoughts, tasks, and relational ties to cultivate meaningful lives and positive identities in various life domains ${ }^{13)}$. More specifically, we propose that psychological needs reach across and connect different life domains, with some needs being more easily satisfied in a professional work identity than in a non-work identity. The work and the non-work context are key in enabling people to craft. Poorly designed jobs or a taxing home situation may prevent people from actively fulfilling their needs. Therefore, occupational health is a shared responsibility between different players. In addition to individual workers, also employers, governmental policies and managers are crucial in supporting worker's individual crafting efforts. In concrete terms, governments could increase childcare support for single-parents. Labor unions could collect and map difficulties that vulnerable workers may face and coordinate collective action to protect their rights and needs. Organizations could communicate understanding for the challenging situation, lower productivity expectations and help workers setting work-private life boundaries. This can for example be achieved by recommending core working times, which are respected by managers, who refrain from connecting with team members outside the agreed working times.

This crisis also carries hope. Supervisors may realize that they can enable workers to work from home without dreaded performance decrements. Employers may even see higher levels of work engagement due to higher levels of job control. In the future, workers may continue making use of these new opportunities to save travel time, travel costs and to more easily juggle work and private life on busy days during the week. This may bring about benefits for the natural environment and polluted cities. Humor and creativity levels have been high to fight boredom, and most people have been challenged to rethink their working methods and communication strategies. Physical distance has decreased in people's mind and people may suddenly have virtual coffee breaks with their colleagues abroad, which would never have happened without the crisis. Teachers may discover new teaching strategies and shy students may eagerly participate in online classes. Awareness and respect for workers that keep our societies running rises, possibly resulting in improved working conditions in the future. New social networks and initiatives emerge to support people struggling with mental problems or who feel lonely. Those new friendships will most likely remain when we return to a new normal. Overall, overcoming this crisis can bring humanity closer together and establish a new sense of a global community which focuses on equality, stability, meaningful work, and a sustainable future for humans and our planet.

\section{References}

1) Hill EJ, Ferris M, Märtinson V (2003) Does it matter where you work? A comparison of how three work venues (traditional office, virtual office, and home office) influence aspects of work and personal/family life. J Vocat Behav 63, 220-41. [CrossRef]

2) Nijp HH, Beckers DGJ, van de Voorde K, Geurts SAE, Kompier MAJ (2016) Effects of new ways of working on work hours and work location, health and jobrelated outcomes. Chronobiol Int 33, 604-18. [Medline] [CrossRef]

3) Biron M, van Veldhoven M (2016) When control becomes a liability rather than an asset: comparing home and office days among part-time teleworkers. J Organ Behav 37, 1317-37. [CrossRef]

4) Holt-Lunstad J, Smith TB, Baker M, Harris T, Stephenson D (2015) Loneliness and social isolation as risk factors for 
mortality: a meta-analytic review. Perspect Psychol Sci 10, 227-37. [Medline] [CrossRef]

5) de Bloom J, Nawijn J, Geurts S, Kinnunen U, Korpela K (2017) Holiday travel, staycations, and subjective wellbeing. J Sustain Tour 25, 573-88. [CrossRef]

6) Newman DB, Tay L, Diener E (2014) Leisure and subjective well-being: a model of psychological mechanisms as mediating factors. J Happiness Stud 15, 555-78. [CrossRef]

7) Ryan RM, Deci EL (2000) Self-determination theory and the facilitation of intrinsic motivation, social development, and well-being. Am Psychol 55, 68-78. [Medline] [CrossRef]

8) Feuerhahn N, Sonnentag S, Woll A (2014) Exercise after work, psychological mediators, and affect: a day-level study. Eur J Work Organ Psychol 23, 62-79. [CrossRef]

9) Kinnunen U, Feldt T, de Bloom J, Sianoja M, Korpela K, Geurts S (2017) Linking boundary crossing from work to nonwork to work-related rumination across time: a variable- and person-oriented approach. J Occup Health Psychol 22, 467-80. [Medline] [CrossRef]

10) Iwasaki Y, Messina ES, Hopper T (2018) The role of leisure in meaning-making and engagement with life. J Posit Psychol 13, 29-35. [CrossRef]

11) Loveday PM, Lovell GP, Jones CM (2018) The importance of leisure and the psychological mechanisms involved in living a good life: a content analysis of best-possible-selves texts. J Posit Psychol 13, 18-28. [CrossRef]

12) de Bloom J, Vaziri H, Tay L, Kujanpää M (2020) An identity-based integrative needs model of crafting: crafting within and across life domains. J Appl Psychol (In Press). [Medline] [CrossRef]

13) Wrzesniewski A, Dutton JE (2001) Crafting a job: revisioning employees as active crafters of their work. Acad Manage Rev 26, 179-201. [CrossRef]

\section{Jessica DE BLOOM}

Academy of Finland Researcher, University of Tampere, Finland Associate Professor, University of Groningen, Netherlands 